\title{
Prognostic significance of mucinous colorectal carcinoma
}

\section{Müsinöz kolorektal karsinomun prognostik önemi}

\author{
Serhat Tokgöz¹, Fatma Buğdaycı Başal ${ }^{2}$, Selim Tamam ${ }^{1}$ \\ ${ }^{1}$ Sağlık Bilimleri Üniversitesi, Dışkapı Yıldırım Beyazıt Eğitim ve Araştırma Hastanesi Genel Cerrahi Kliniği, \\ Ankara, Türkiye \\ ${ }^{2}$ Sağlık Bilimleri Üniversitesi,Ankara Dr.A.Y. Onkoloji Eğitim ve Araştırma Hastanesi, Medikal Onkoloji \\ Kliniği, Ankara, Türkiye
}

Dergiye Ulaşma Tarihi: 12.11.2019 Dergiye Kabul Tarihi30.12.2019 Doi: $10.5505 /$ aot.2020.57338

\section{ÖZET}

GİRIS ve AMAÇ: Müsinöz adenokarsinom kolorektal adenokanserlerin alt tipidir. Diğer müsinöz olmayan adenokanserlerden (MOA) genetik, klinik ve patolojik farklılıkları olmasına rağmen müsinöz adenokanserlerin( MA) prognostik önemi halen tartışmalıdır. Bu çalışmanın amacı kolorektal müsinöz adenokarsinomun klinikopatolojik özelliklerini ve prognostik önemini değerlendirmektir. YÖNTEM ve GEREÇLER: Ocak 2012 ile Aralık 2018 tarihleri arasında kliniğimizde kolon adenokanseri nedeniyle opere edilen 413 hastanın verileri incelendi. Analizlerde yaş, cinsiyet, lokasyon, tümör büyüklüğü, invazyon derinliği, lenf nodu metastazı, uzak metastaz varlığı, operasyon yöntemi ve aciliyeti, perinöral ve lenfovasküler invazyon varlığı, müsinöz histoloji varllğı prognostik faktör olarak incelendi. BULGULAR: Müsinöz grupta hastalık daha çok kolonda lokalize, $5 \mathrm{~cm}$ 'den daha büyük olma eğiliminde ve invazyon derinliği daha fazla idi. Tüm grubun 3 yıllık genel sağkalımı $\% 74,5$ yıllık sağkalımı $\% 63$ olarak saptandı. Müsinöz grupta sağkalım oranlarının daha düşük olduğu (3 yıllık genel sağkalım; MA \% 58, MOA \% $75 \mathrm{p}=0.01 ; 5$ yıllık genel sağkalım; MA \% 58, MOA \% 64 p=0.01) gözlendi. Tek değişkenli analizlerde tümör büyüklüğü ve cinsiyet dışında diğer tüm değişkenler anlamlı olarak fark yaratmakta idi. Çok değişkenli analizlerde yaşın 65 ve üzerinde olması, uzak metastaz varlığı, perinöral invazyon varlığı, acil opere edilmiş

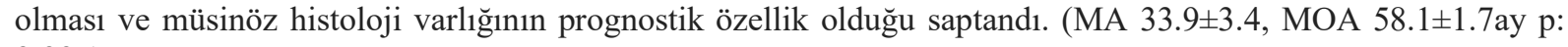
0.006).

TARTIŞMA ve SONUÇ: MA'un biyolojik davranışı müsinöz olmayan adenokarsinomlara göre daha kötüdür. Kolorektal kanserlerde tedavi başarısını artırmak için kanserlerin alt tiplerine, histolojik özelliklerine ve genetik özelliklerine dayalı bireyselleştirilmiş tedavilerin ve takiplerin geliştirilmesi gerekmektedir.

Anahtar Kelimeler: Müsinöz, kolorektal kanser, prognostik faktör

\begin{abstract}
INTRODUCTION: Mucinous adenocarcinoma is a subtype of colorectal adenocarcinomas. Although it differs from non-mucinous adenocarcinomas (nMA) genetically, clinically and pathologically, the prognostic significance of mucinous adenocarcinomas (MA) is controversial. The aim of this study is to evaluate the clinicopathological features and prognostical significance of colorectal mucinous adenocarcinoma. METHODS: The datas of 413 patients that has been operated in our clinic between January 2012 and December 2018 due to adenocarcinoma of colon were scanned. In the analyses, age, sex, location, tumour size, invasion depth, lymph node metastasis, existence of distant metastasis, operation method and degree of urgency, perineural and lymphovascular invasion, mucinous histology were investigated as prognostic factors. RESULTS: In the mucinous group, the disease was more localized in the colon, tending to be greater than $5 \mathrm{~cm}$, and the depth of invasion was greater. All patients had a 3-year overall survival rate of $74 \%$ and a 5 -year overall survival rate of $63 \%$. Survival rates were lower in the mucinous group (3-year overall survival; MA $58 \%$, nMA $75 \% \mathrm{p}=0.01 ; 5$-year overall survival; MA 58\%, nMA 64\% $\mathrm{p}=0.01$ ). In univariate analyzes, all variables except tumor size and gender were significantly different. In multivariable analyses, it is observed that being over 65 years, distant metastasis, perineural invasion, the urgency of the operation and mucinous histology presence were

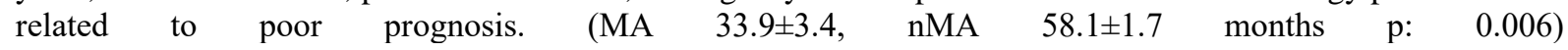
DISCUSSION AND CONCLUSION: Biological behaviour of MA is worse than nonmucinous adenocarcinomas. It is mandatory to develop individual therapies according to subtypes, histological and genetical features of cancers in order to increase the therapeutic success in colorectal cancers.
\end{abstract}

Keywords: Mucinous, colorectal cancer, prognostic factor

Adress for correspondence: Uzm. Dr. Serhat Tokgöz [serhat.tokgoz@ yahoo.com] dışkapı yıldırım beyazıt eğitim ve araştırma hastanesi genel cerrahi kliniği şehit Ömer Halisdemir cad altındağ 06110 ANKARA - Türkiye

e-mail: msaydam2008@ hotmail.com

Available at www.actaoncologicaturcica.com

Copyright $\mathbb{C}$ Ankara Onkoloji Hastanesi 


\section{GíRiş}

Kolorektal kanserler dünyada en sik görülen 3 . kanser türüdür(1). Kolorektal kanserlerin $\% 90$ 'dan fazlasinı mukozanın epitelyal hücrelerinden köken alan adenokarsinomlar oluşturmaktadır(2). Müsinöz adenokarsinom (MA) ise neoplastik hücrelerin aşırı müsinin salgılandığ 1 ve extraselüler alanın \%50'sinden fazlasını müsinin oluşturduğu histolojik bir alt tiptir. Yapılan çalışmalarda MA'ların tüm kolorektal kanserlerin \%3,9-20 sini oluşturduğu bildirilmektedir (3-5).

Tümörün evresi, derecesi, preoperatif karsinoembriyojenik antijen seviyesi, lenfovasküler invazyon gibi birçok prognostik faktör tanımlanmış olmasına rağmen MA'nın prognostik önemi halen tartışmalıdır. Birçok çalışmada müsinöz histoloji prognostik faktör olarak kabul edilmemektedir ancak müsinöz ve müsinöz olmayan adenokarsinomlar (MOA) arasında klinik, patolojik ve genetik özellikler açısından belirgin farklılar mevcuttur (6-8).

Son y1llarda cerrahi ve medikal tedavilerdeki ilerlemeler nedeniyle kolorektal kanserlerde sağkalım oranları artmıştır (9-11). Kolorektal kanserler için cerrahi tek küratif tedavi yöntemidir fakat lokal bölgesel ve uzak metastaz ile nüks oranı yüksektir. Bu nedenle prognostik ve prediktif belirteçler hastalığın durumunun belirlenmesinde önemli hale gelmektedir.

$\mathrm{Bu}$ çalışmanın amacı kolorektal müsinöz adenokarsinomun klinikopatolojik özelliklerini ve prognostik önemini değerlendirmektir.

\section{MATERYAL-METOD}

Ocak 2012 ile Aralık 2018 tarihleri arasında kliniğimizde kolon adenokanseri nedeniyle opere edilen 413 hasta çalışmaya dahil edildi. Hastaların klinikopatolojik özellikleri hasta dosyalarından ve bilgi işlem sistemindeki kayitlı bilgilerinden elde edildi. Histopatolojik özelliklerine göre müsinöz adenokarsinom (MA) ve müsinöz olmayan adenokarsinom (MOA) olarak siniflandırıldı. Appendiks ve diğer gastrointestinal müsinöz adenokarsinomları çalışmaya dahil edilmedi. Evre 4 dışındaki hastalara R0 rezeksiyon uyguland 1 ve evrelerine göre kemoradyoterapi verildi. Opere edilen 413 hastada demografik ve klinikopatolojik özellikleri değerlendirmek amaciyla yaş, cinsiyet, tümör lokalizasyonu, tümör boyutu, invazyon derinliği (T), lenf nodu metastazı varlığı (N), uzak metastaz varlığ1 (M), operasyon öncesi serum CEA düzeyleri, operasyon yöntemi, lenfovasküler ve perinöral invazyon, operasyon aciliyet durumu incelendi.

İstatistiki analizler için SPSS (Statistical Package for Social Sciences for Windows) 18.0 programı kullanıldı. Çalışma verileri değerlendirilirken sürekli değişkenlerin dağılım tipine göre ortalama veya ortanca değerleri; kategorik verilerin yüzde (\%) ile sıklığ 1 verildi. Müsinöz ve müsinöz olmayan grupların klinikodemografik özellikleri Pearson ki-kare testi ile incelendi. Sağkalım analizinde; genel sağkalım operasyon tarihi ile ölüm tarihi arasındaki süre olarak kabul edildi. Analiz esnasında halen yaşayan hastalarda analiz tarihi değerlendirmeye alındı. Takip süresi, tan1 tarihi ile son kontrol tarihi arasındaki süre olarak tanımlandı.

Tüm örneklemin median takip süresi ve sağkalım süresi için Kaplan Meier yöntemi kullanıldı. Median sağkalıma ulaşılamadığı için 3 yıllık ve 5 yıllık genel sağkalım analizleri yapıldı. Her iki gruptaki fark incelendi. Tek değişkenli analizlerde iki grup arasında anlamlı fark sağlanabilecek, 3 ve 5 y1llık genel sağkalıma etki edebilecek özellikler incelendi. Analizlerde yaş, cinsiyet, lokasyon, tümör büyüklüğü, invazyon derinliği, lenf nodu metastazı, uzak metastaz varlığ 1 , operasyon yöntemi ve aciliyeti, perinöral ve lenfovasküler invazyon varlığ müsinöz histoloji varlığ 1 prognostik faktör olarak incelendi. Çok değişkenli analizde, tek değişkenli analizlerde belirlenen olası faktörler kullanılarak sağkalımı öngörmedeki bağımsız etkenler geriye doğru seçim yöntemi ile Cox regresyon analizi kullanılarak incelendi. Sağkalım üzerine benzer etki gösteren birbiri ile ilişkili parametrelerden modele klinik açıdan anlamlı olanlar seçildi. Model uyumu ve dönemsel riskin oransallığ varsayımları rezidüel (Schoenfeld ve Martingale) analizleri kullanılarak değerlendirildi. Tip 1 hata düzeyinin \% 5'in altında olan durumlar istatistiksel anlamlı olarak yorumland. 
Sonuçlar \% 95'lik güven aralığında ve anlamlılık $\mathrm{p}<0.05$ düzeyinde değerlendirildi.

\section{BULGULAR}

Çalışmaya dahil edilen 413 hastanın çoğunluğu erkek hasta (E/K; \% $60.3 / \%$ 39.7) olup ortalama yaş tüm grupta 63 (26-92; St D: 12.3) idi. Tümör lokalizasyonu rektum (\% 38.8), sol kolon (\% 35.8) ve sağ kolon (\% 25.4) idi. Ortalama tümör çap1 $43.6 \mathrm{~mm}(1-150 \mathrm{~mm}$; St D: 19.8) olarak saptand1. Analizlere tüm evrelerdeki hastalar (Evre I \% $14 \mathrm{n}=58$, evre II $\% 36.1 \mathrm{n}=149$, evre III \% $34.9 \mathrm{n}=144$, evre IV $\% 15 \mathrm{n}=62)$ dahil edildi. Laparatomi $330(\%$ 79.9) hastaya, laparoskopi 56 (\%13.6) hastaya uygulanmıştı ve laparoskopiden laparatomiye geçilen (konversiyon) 27 (\% 6.5) hasta mevcuttu. Histopatolojik incelemede müsinöz (\% 9.4, $\mathrm{n}=39)$ ve müsinöz olmayan adenokarsinom (\% 90.6, $\mathrm{n}=374)$ oranlarında bulunuyordu. Hastaların 124'ünde ( $\% 30)$ lenfovasküler invazyon, 108 'inde (\% 26.2) perinöral invazyon saptanmıştı. Hastaların yaklaşık beşte biri ( $\% 22.5, \mathrm{n}=93)$ acil opere olmuştu.

Histopatolojisi müsinöz olan ve müsinöz olmayan hastaların prognostik özelliklerinin karşılaştırılması planlanan çalışmamızda müsinöz özellik taşıyan hastalar ve müsinöz özellikte olmayan hastalar gruplandırılarak pearson ki-kare testi ile demografik ve klinikopatolojik özelliklerine göre karşılaştırıldı (Tablo-1). Tümör lokalizasyonu, tümör büyüklüğü ve invazyon derinliği açısından iki grup arasında anlamlı fark saptandı. Müsinöz grupta hastalık daha çok kolonda lokalize, $5 \mathrm{~cm}$ 'den daha büyük olma eğiliminde ve invazyon derinliği daha fazla idi.

Sağkalım analizinde tüm grupta median genel sağkalıma ulaşılamadı (Şekil 1). $\mathrm{Bu}$ nedenle hastaların 3 yıllık ve 5 yıllık genel sağkalımları incelendi. Tüm grubun 3 yıllık genel sağkalımı \%74,5 yıllık sağkalımı $\% 63$ olarak saptand 1 (Şekil 2-3). Hastaların histopatolojilerine göre müsinöz ve müsinöz olmayan grup olarak 3 yıllık ve 5 yıllık genel sağkalımları incelendiğinde müsinöz grupta sağkalım oranlarının daha düşük olduğu (3 yıllık genel sağkalım; MA \% 58, MOA \% 75 $\mathrm{p}=0.01 ; 5$ y1llık genel sağkalım; MA \% 58, MOA \% $64 \mathrm{p}=0.01$ ) gözlendi (Şekil 4-5).
Müsinöz ve müsinöz olmayan adenokarsinom histopatolojisine sahip tüm grupta yapılan tek değişkenli analizlerde literatür ile uyumlu olarak cinsiyet, yaşın 65 yaş üzerinde olup olmamas1, tümör lokalizasyonu, tümör boyutunun $5 \mathrm{~cm}$ üzerinde olup olmaması, invazyon derinliği, lenf nodu metastazı varlığ1, uzak metastaz varlığ1, operasyon yöntemi, lenfovasküler invazyon, perinöral invazyon, acil operasyon varlığ ve müsinöz histoloji varlığı incelendi (Tablo-2). Ayrıca müsinöz histopatoloji özelliğinin prognostik önemi incelendi.

Tek değişkenli analizlerde tümör büyüklüğü ve cinsiyet dışında diğer tüm değişkenler anlamlı olarak fark yaratmakta idi. Tek değiş̧enli analizlerde anlamlı fark yaratan değişkenler çok değişkenli analizlerde incelendi. Çok değişkenli analizlerde yaşın 65 ve üzerinde olması, uzak metastaz varlığı, perinöral invazyon varlığ müsinöz histoloji varlığının prognostik özellik

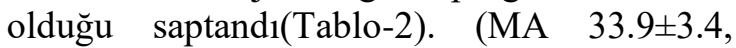
MOA 58.1 \pm 1.7 ay p:0.006)

Yaşın 65 altı olması ölüm oranını \% 49 azaltmaktaydı. Tümör yerleşim yeri kolon olan hastalar rektum olan hastalara göre 1.58 kat daha fazla ölüm oranına sahip olarak saptandı. Uzak metastaz varlığ ölüm oranını 6.16 kat, acil operasyon varlığ 2.05 kat ve müsinöz histopatoloji varlığ 2.42 kat arttırmaktaydı. Hastalarda perinöral invazyon olamaması ölüm oranın $1 \% 47$ azaltmaktaydı.

Sonuç olarak müsinöz histoloji varlığının incelendiği çalışmamızda müsinöz histolojiye sahip hastalarda daha fazla tümör boyutu, invazyon derinliği ve kolon yerleşimi saptandı. Ayrıca yapılan tek ve çok değişkenli analizlerde müsinöz histopatolojinin kötü prognostik faktör olduğu gösterildi (Şekil 6,7).

Tablo 1. Müsinöz ve müsinöz olmayan adenokarsinomlu hastalarda klinikopatolojik özelliklerin karşılaştırılması

\begin{tabular}{|c|c|c|c|c|}
\hline \multicolumn{2}{|l|}{ Özellikler } & \multirow{2}{*}{$\begin{array}{c}\begin{array}{c}\text { MOA } \\
(n=374\end{array} \\
) \\
215\end{array}$} & \multirow{2}{*}{$\begin{array}{c}\begin{array}{c}\text { MA } \\
(\mathbf{n}=39 \\
)\end{array} \\
22\end{array}$} & \multirow{2}{*}{$\begin{array}{c}\mathbf{P *} \\
0,89\end{array}$} \\
\hline \multirow{2}{*}{ Yaş } & $<65$ & & & \\
\hline & $\geq 65$ & 159 & 17 & 7 \\
\hline \multirow{2}{*}{ Cinsiyet } & Kadın & 145 & 19 & 0,22 \\
\hline & Erkek & 229 & 20 & 7 \\
\hline \multirow{2}{*}{ Lokasyon } & Kolon & 222 & 32 & $\mathbf{0 , 0 0}$ \\
\hline & Rektum & 152 & 7 & 6 \\
\hline \multirow{2}{*}{$\begin{array}{l}\text { Tümör } \\
\text { büyüklüğü(c }\end{array}$} & $<5$ & 245 & 17 & $\mathbf{0 , 0 0}$ \\
\hline & $\geq 5$ & 129 & 22 & 7 \\
\hline
\end{tabular}

Adress for correspondence: Uzm. Dr. Serhat Tokgöz [serhat.tokgoz@ yahoo.com] dışkapı yıldırım beyazıt eğitim ve araştırma hastanesi genel cerrahi kliniği şehit Ömer Halisdemir cad altındağ 06110 ANKARA - Türkiye

e-mail: msaydam2008@hotmail.com

Available at www.actaoncologicaturcica.com

Copyright (C)Ankara Onkoloji Hastanesi 


\begin{tabular}{|c|c|c|c|c|}
\hline \multicolumn{5}{|l|}{ m) } \\
\hline \multirow{2}{*}{$\begin{array}{l}\text { İnvazyon } \\
\text { derinliği (T) }\end{array}$} & T1, T2 & 72 & 2 & \multirow{2}{*}{$\begin{array}{c}0,02 \\
9\end{array}$} \\
\hline & T3, T4 & 302 & 37 & \\
\hline \multirow{2}{*}{$\begin{array}{l}\text { Lenf nodu } \\
\text { metastazi (N) }\end{array}$} & No & 202 & 19 & \multirow{2}{*}{$\begin{array}{c}0,52 \\
8\end{array}$} \\
\hline & N1, N2 & 172 & 20 & \\
\hline \multirow{2}{*}{$\begin{array}{l}\text { Uzak } \\
\text { metastaz } \\
\text { (M) }\end{array}$} & M0 & 319 & 30 & \multirow{2}{*}{$\begin{array}{c}0,16 \\
9\end{array}$} \\
\hline & M1 & 55 & 9 & \\
\hline \multirow[b]{2}{*}{$\begin{array}{l}\text { Operasyon } \\
\text { yöntemi }\end{array}$} & $\begin{array}{l}\text { Laparosko } \\
\text { pi }\end{array}$ & 54 & 2 & \multirow[b]{2}{*}{$\begin{array}{c}0,29 \\
9\end{array}$} \\
\hline & $\begin{array}{l}\text { Laparotom } \\
\text { i, } \\
\text { Konversiyo } \\
\text { n }\end{array}$ & 320 & 37 & \\
\hline \multirow{2}{*}{$\begin{array}{l}\text { Lenfovasküle } \\
\text { r invazyon }\end{array}$} & Var & 107 & 17 & \multirow{2}{*}{$\begin{array}{c}0,05 \\
2 \\
\end{array}$} \\
\hline & Yok & 267 & 22 & \\
\hline \multirow{2}{*}{$\begin{array}{l}\text { Perinöral } \\
\text { invazyon }\end{array}$} & Var & 100 & 8 & \multirow{2}{*}{$\begin{array}{c}0,40 \\
0\end{array}$} \\
\hline & Yok & 274 & 31 & \\
\hline \multirow{2}{*}{ Aciliyet } & Acil & 83 & 10 & \multirow{2}{*}{$\begin{array}{c}0,62 \\
3 \\
\end{array}$} \\
\hline & Elektif & 291 & 29 & \\
\hline \multirow{2}{*}{ Exitus } & Var & 81 & 12 & \multirow{3}{*}{$\begin{array}{c}0,19 \\
5\end{array}$} \\
\hline & Yok & 293 & 27 & \\
\hline \multicolumn{2}{|l|}{ Toplam } & 374 & 39 & \\
\hline
\end{tabular}

*Pearson Chi-Square

Tablo 2. Müsinöz ve müsinöz olmayan adenokarsinomlu hastalarda genel sağ kalıma etki eden faktörler

\begin{tabular}{|c|c|c|c|c|c|c|c|}
\hline & & $\begin{array}{c}\text { Tek } \\
\text { değiş } \\
\text { kenli } \\
\text { anali } \\
\text { z }\end{array}$ & $\begin{array}{c}\text { Çok } \\
\text { değiş } \\
\text { kenli } \\
\text { anali } \\
\text { z }\end{array}$ & & & & \\
\hline & & $\begin{array}{c}\text { Orta } \\
\text { lama } \\
\text { sağk } \\
\text { alım } \\
\text { süre } \\
\text { si } \pm \\
\text { SH*( } \\
\text { Ay) }\end{array}$ & $\begin{array}{c}\% 95 \\
\text { GA* } \\
*\end{array}$ & $\mathbf{P} * * *$ & HR & $\begin{array}{l}\% 95 \\
\text { GA }\end{array}$ & $\begin{array}{c}\mathbf{P} * * * \\
*\end{array}$ \\
\hline \multirow{2}{*}{$\begin{array}{l}\text { Yaş } \\
\text { (yıl) }\end{array}$} & $\geq 65$ & $\begin{array}{l}51.3 \\
\pm 2.6\end{array}$ & $\begin{array}{c}46.1- \\
56.5\end{array}$ & \multirow{2}{*}{$\begin{array}{c}0.00 \\
1\end{array}$} & \multirow{2}{*}{0.49} & \multirow{2}{*}{$\begin{array}{c}0.32- \\
0.75\end{array}$} & \multirow{2}{*}{$\begin{array}{c}0.00 \\
1\end{array}$} \\
\hline & $<65$ & $\begin{array}{c}61.4 \\
\pm 2\end{array}$ & $\begin{array}{c}57.3- \\
65.3\end{array}$ & & & & \\
\hline \multirow{2}{*}{$\begin{array}{l}\text { Cins } \\
\text { iyet }\end{array}$} & $\begin{array}{l}\text { Erke } \\
\mathbf{k}\end{array}$ & $\begin{array}{l}55.7 \\
\pm 2.2\end{array}$ & $\begin{array}{c}51.3- \\
60.2\end{array}$ & \multirow{2}{*}{$\begin{array}{c}0.46 \\
3\end{array}$} & & & \\
\hline & $\begin{array}{l}\text { Kadı } \\
\text { n }\end{array}$ & $\begin{array}{l}58.4 \\
\pm 2.4\end{array}$ & $\begin{array}{c}53.7- \\
63.2\end{array}$ & & & & \\
\hline \multirow{2}{*}{$\begin{array}{l}\text { Lok } \\
\text { asyo } \\
\text { n }\end{array}$} & $\begin{array}{l}\text { Kolo } \\
\text { n } \\
\end{array}$ & $\begin{array}{l}53.6 \\
\pm 2.1\end{array}$ & $\begin{array}{c}49.4- \\
57.8\end{array}$ & \multirow{2}{*}{$\begin{array}{c}0.00 \\
6\end{array}$} & \multirow[b]{2}{*}{1.58} & \multirow{2}{*}{$\begin{array}{c}0.98- \\
2.54\end{array}$} & \multirow{2}{*}{$\begin{array}{c}0.05 \\
8\end{array}$} \\
\hline & $\begin{array}{l}\text { Rekt } \\
\text { um }\end{array}$ & $\begin{array}{l}62.3 \\
\pm 2.4\end{array}$ & $\begin{array}{l}57.5- \\
67.1 \\
\end{array}$ & & & & \\
\hline \multirow{2}{*}{$\begin{array}{l}\text { Tüm } \\
\text { ör } \\
\text { büyü } \\
\text { klü̆ğ } \\
\ddot{\mathbf{u}} \\
(\mathrm{cm})\end{array}$} & $\geq 5$ & $\begin{array}{l}55.4 \\
\pm 2.7\end{array}$ & $\begin{array}{c}50.1- \\
60.8\end{array}$ & \multirow[b]{2}{*}{$\begin{array}{c}0.59 \\
3\end{array}$} & & & \\
\hline & $<5$ & $\begin{array}{c}57.8 \\
\pm 2\end{array}$ & $\begin{array}{c}53.5- \\
61.7\end{array}$ & & & & \\
\hline \multirow{2}{*}{$\begin{array}{l}\text { İnva } \\
\text { zyon } \\
\text { deri } \\
\text { nliği } \\
\text { (T) }\end{array}$} & $\begin{array}{l}\text { T1, } \\
\text { T2 }\end{array}$ & $\begin{array}{l}66.2 \\
\pm 2.9 \\
\end{array}$ & $\begin{array}{c}60.4- \\
72.1 \\
\end{array}$ & \multirow{2}{*}{$\begin{array}{c}0.01 \\
0\end{array}$} & \multirow[b]{2}{*}{1.00} & \multirow{2}{*}{$\begin{array}{c}0.47- \\
2.13\end{array}$} & \multirow{2}{*}{$\begin{array}{c}0.99 \\
2\end{array}$} \\
\hline & $\begin{array}{l}\text { T3, } \\
\text { T4 }\end{array}$ & $\begin{array}{l}53.4 \\
\pm 1.8\end{array}$ & $\begin{array}{c}49.3- \\
57\end{array}$ & & & & \\
\hline Lenf & No & 62.2 & 58.1- & 0.00 & 0.83 & $0.52-$ & 0.58 \\
\hline
\end{tabular}

\begin{tabular}{|c|c|c|c|c|c|c|c|}
\hline \multirow{2}{*}{$\begin{array}{l}\text { nodu } \\
\text { meta } \\
\text { stazı } \\
(\mathrm{N})\end{array}$} & & \pm 2.1 & 66.3 & \multirow[t]{2}{*}{1} & & \multirow[t]{2}{*}{1.34} & \multirow[t]{2}{*}{7} \\
\hline & $\begin{array}{l}\mathrm{N} \\
\text { pozit } \\
\text { if }\end{array}$ & $\begin{array}{l}50.4 \\
\pm 2.3\end{array}$ & $\begin{array}{c}45.7- \\
55.1\end{array}$ & & & & \\
\hline \multirow{2}{*}{$\begin{array}{l}\text { Uza } \\
\text { k } \\
\text { meta } \\
\text { staz } \\
\text { (M) }\end{array}$} & Var & $\begin{array}{l}24.8 \\
\pm 2.9\end{array}$ & $\begin{array}{l}18.9- \\
30.6\end{array}$ & \multirow{2}{*}{$\begin{array}{l}<0.0 \\
01\end{array}$} & \multirow[b]{2}{*}{6.16} & \multirow{2}{*}{$\begin{array}{c}3.97- \\
9.55\end{array}$} & \multirow{2}{*}{$\begin{array}{c}<0.0 \\
01\end{array}$} \\
\hline & Yok & $\begin{array}{l}63.5 \\
\pm 1.5\end{array}$ & $\begin{array}{c}60.4- \\
66.6\end{array}$ & & & & \\
\hline \multirow{2}{*}{$\begin{array}{l}\text { Ope } \\
\text { rasy } \\
\text { on } \\
\text { yönt } \\
\text { emi }\end{array}$} & $\begin{array}{l}\text { Lap } \\
\text { arot } \\
\text { omi }\end{array}$ & $\begin{array}{l}54.8 \\
\pm 1.8\end{array}$ & $\begin{array}{c}51.2- \\
58.5\end{array}$ & \multirow{2}{*}{$\begin{array}{c}0.00 \\
3\end{array}$} & \multirow{2}{*}{0.91} & \multirow{2}{*}{$\begin{array}{c}0.12- \\
6.60\end{array}$} & \multirow{2}{*}{$\begin{array}{c}0.32 \\
0\end{array}$} \\
\hline & $\begin{array}{l}\text { Lap } \\
\text { aros } \\
\text { kopi }\end{array}$ & $\begin{array}{l}69.6 \\
\pm 2.5\end{array}$ & $\begin{array}{l}64.7- \\
74.5\end{array}$ & & & & \\
\hline \multirow{2}{*}{$\begin{array}{l}\text { Lenf } \\
\text { ovas } \\
\text { küle } \\
\text { r } \\
\text { inva } \\
\text { zyon }\end{array}$} & Var & $\begin{array}{l}50.2 \\
\pm 3.1\end{array}$ & $\begin{array}{c}44- \\
56.4\end{array}$ & \multirow[b]{2}{*}{$\begin{array}{c}0.00 \\
6\end{array}$} & \multirow[b]{2}{*}{0.91} & \multirow[b]{2}{*}{$\begin{array}{c}0.56- \\
1.46\end{array}$} & \multirow[b]{2}{*}{$\begin{array}{c}0.69 \\
7\end{array}$} \\
\hline & Yok & $\begin{array}{l}58.9 \\
\pm 1.8\end{array}$ & $\begin{array}{l}55.3- \\
62.5\end{array}$ & & & & \\
\hline \multirow{2}{*}{$\begin{array}{l}\text { Peri } \\
\text { nöra } \\
\text { I } \\
\text { inva } \\
\text { zyon }\end{array}$} & Var & $\begin{array}{c}37 \pm 2 \\
.6 \\
\end{array}$ & $\begin{array}{c}31.8- \\
42.2 \\
\end{array}$ & \multirow{2}{*}{$\begin{array}{l}<0.0 \\
01\end{array}$} & \multirow[b]{2}{*}{0.47} & \multirow{2}{*}{$\begin{array}{c}0.30- \\
0.73\end{array}$} & \multirow{2}{*}{$\begin{array}{c}0.00 \\
1\end{array}$} \\
\hline & Yok & $\begin{array}{l}62.2 \\
\pm 1.7\end{array}$ & $\begin{array}{l}58.8- \\
65.6\end{array}$ & & & & \\
\hline \multirow{2}{*}{$\begin{array}{l}\text { Acili } \\
\text { yet }\end{array}$} & Acil & $\begin{array}{l}39.9 \\
\pm 3.3\end{array}$ & $\begin{array}{c}33.2- \\
46.5\end{array}$ & \multirow{2}{*}{$\begin{array}{l}<0.0 \\
01\end{array}$} & \multirow{2}{*}{2.05} & \multirow{2}{*}{$\begin{array}{l}1.31- \\
3.20\end{array}$} & \multirow{2}{*}{$\begin{array}{c}0.00 \\
1\end{array}$} \\
\hline & $\begin{array}{l}\text { Elek } \\
\text { tif }\end{array}$ & $\begin{array}{l}62.1 \\
\pm 1.7 \\
\end{array}$ & $\begin{array}{l}58.7- \\
65.4 \\
\end{array}$ & & & & \\
\hline \multirow{2}{*}{$\begin{array}{l}\text { Müsi } \\
\text { nöz } \\
\text { histo } \\
\text { loji }\end{array}$} & MA & $\begin{array}{l}33.9 \\
\pm 3.4 \\
\end{array}$ & $\begin{array}{l}27.1- \\
40.7 \\
\end{array}$ & \multirow{2}{*}{$\begin{array}{c}0.02 \\
3\end{array}$} & \multirow{2}{*}{2.42} & \multirow{2}{*}{$\begin{array}{c}1.29- \\
4.54\end{array}$} & \multirow{2}{*}{$\begin{array}{c}0.00 \\
6\end{array}$} \\
\hline & $\begin{array}{l}\text { MO } \\
\text { A }\end{array}$ & $\begin{array}{l}\mathbf{5 8 . 1} \\
\pm 1.7\end{array}$ & $\begin{array}{l}54.7- \\
61.4\end{array}$ & & & & \\
\hline $\begin{array}{l}\text { Topl } \\
\text { am }\end{array}$ & & $\begin{array}{l}57.2 \\
\pm 1.6\end{array}$ & $\begin{array}{l}54- \\
60.5\end{array}$ & & & & \\
\hline \multicolumn{5}{|c|}{$\begin{array}{l}\text { *Standart Hata } \\
* * * \text { Kaplan-Me }\end{array}$} & \multicolumn{3}{|c|}{ **Güven Aralığ 1} \\
\hline
\end{tabular}

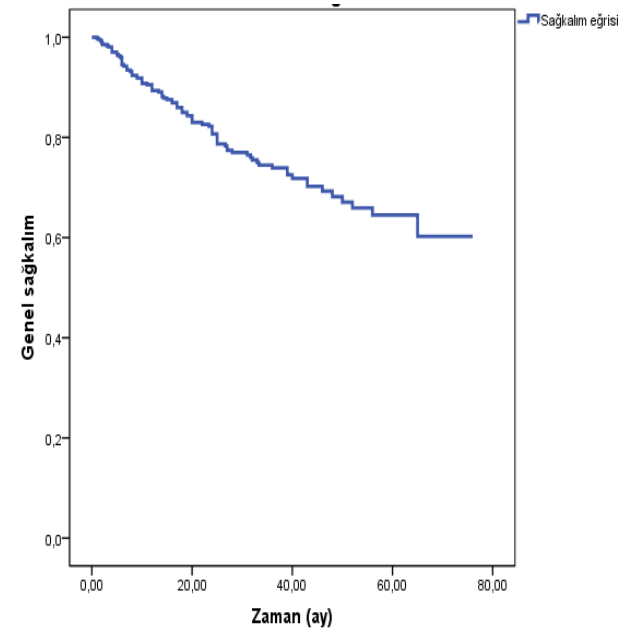

Şekil 1: Genel sağ kalım eğrisi

Adress for correspondence: Uzm. Dr. Serhat Tokgöz [serhat.tokgoz@ yahoo.com] dışkapı yıldırım beyazıt eğitim ve araştırma hastanesi genel cerrahi kliniği şehit Ömer Halisdemir cad altındağ 06110 ANKARA - Türkiye

e-mail: msaydam2008@hotmail.com

Available at www.actaoncologicaturcica.com

Copyright $\mathbb{C}$ Ankara Onkoloji Hastanesi 

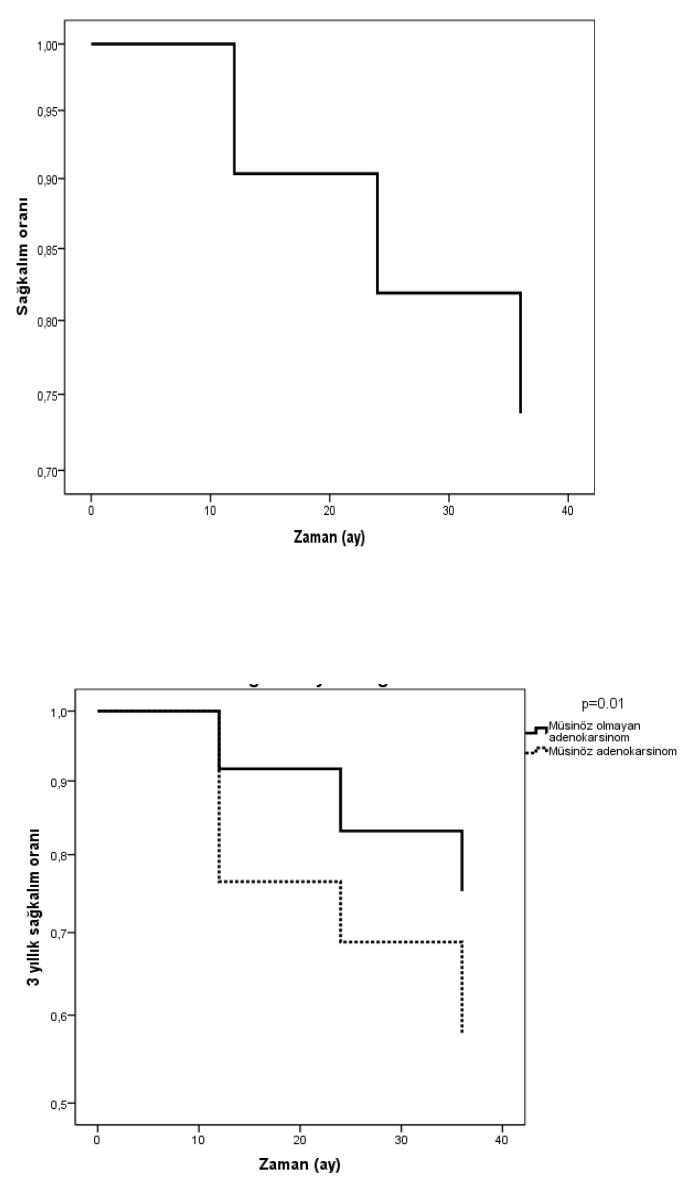

Şekil 2: 3 yıllık sağ kalım eğrisi

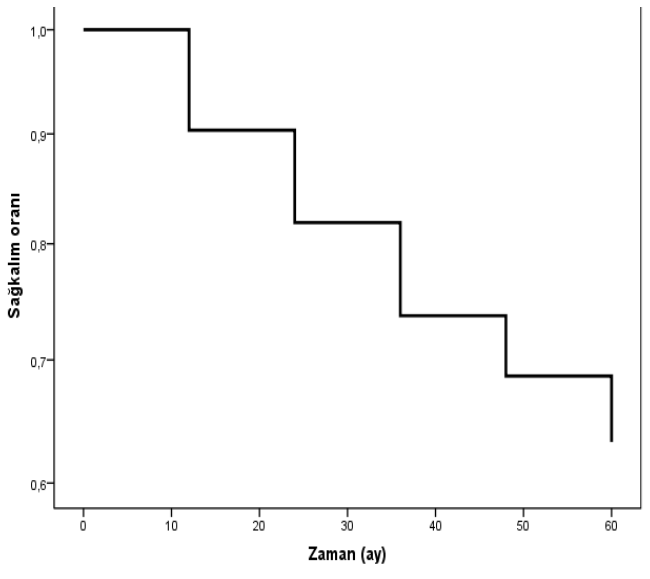

Şekil 3: 5 yıllık sağ kalım eğrisi

\section{TARTIŞMA}

Kolorektal kanserlerin nadir görülen bir alt tipi olan müsinöz adenokarsinomların klinikopatolojik ve prognostik önemi halen tartışmalıdır. Müsinöz ve müsinöz olmayan kolorektal karsinomlar arasındaki farklılıkları araştıran birçok çalışmada MA daha kötü prognoza sahip olduğu gösterilse de bunu desteklemeyen de birçok çalışma mevcuttur (12-14). Bazı çalışmalarda da ise sadece evre 3-4 veya rektuma sinırlı MA'ların prognozlarının daha kötü olduğunu bildirilmektedir $(15,16)$. Hem Amerikan Kanser Ortak Komitesi hem de Amerikan Patologlar Koleji, MA alt tipinin istatistiksel olarak anlamlı bir prognostik faktör olmadığını düşünmektedir (16,17). Çalışmalarda ki çelişkiler ise kolorektal kanserin epidemiyolojisindeki coğrafi ve rrksal farklılıklar, MA'nın tanımlanma kriterlerinde ki eşitsizlikler, opere edilmeyen hastaların çalışmalara dahil edilmemesi ve örneklem büyüklüğünün yetersizliği ile açılanmaktadır (16).

$\mathrm{Bu}$ çalışmada kolorektal adenokarsinom nedeni ile opere edilen 413 vaka incelendi; bunların \%9,4'ünü müsinöz histolojiye sahip adenokarsinomlar oluşturmaktayd 1 ve bu literatürde bildirilen \%3,9-19 oranları ile uyumluydu (18). Daha önce yapılan çalışmalarla benzer şekilde hastaların klinikopatolojik özelliklerinin analizinde MA grubunda hastalığın daha çok kolona lokalize olduğu, tümörlerin $5 \mathrm{~cm}$ 'den daha büyük ve invazyon derinliğinin daha fazla olduğu görüldü (16). Bununla birlikte birçok çalışmada MA'lar daha genç yaşlarda görülmekte, lenf nodu ve uzak metastaz oranı MOA'lara göre daha fazla olduğu bildirilmektedir (19). Ancak bizim çalışmamızda iki grup arasında yaş, lenf nodu ve uzak metastaz açısından istatistiksel olarak anlamlı fark saptanmamıştır. Daha önceki çalışmalarda müsinöz adenokarsinom için kadınlarda daha fazla görüldüğü bildirilmiş olsa da çalışmamızda kadın-erkek oranı (19/20) yaklaşık olarak eşit bulunmuştur (18).

Amerikan patologlar koleji tarafindan hastalıksız sağ kalım ve toplam sağ kalım üzerine en önemli prognostik faktör olarak kabul edilen tümörün derinliği $(\mathrm{T})$, lenf nodu durumu $(\mathrm{N})$, uzak metastaz varlığ $1(\mathrm{M})$ ve 
lenfovaskular invazyon varlığı bizim çalışmamızda da tek değişkenli analizlerde prognostik faktör olarak gösterilmiştir (16). Çok değişkenli analizlerde ise yaşın 65 ve üzerinde olması, uzak metastaz varlığı, perinöral invazyon varlığı, acil opere edilmiş olması ve müsinöz histoloji varlığı prognostik faktör olarak saptanmıştır.

MA'ların MOA'lara göre daha kötü karakteristik özelliklere sahip olmalarının nedeni tam olarak anlaşılmamıştır. Sugarbaker ve arkadaşları yaptığı bir çalışmada tümör hücreleri tarafindan üretilen aşırı müsinin doku planları arasından peritoneal kaviteye ulaşması ve üretilen müsinin lenfatik drenajı sonrası lenf nodu tutulumunun fazla olması hipotezi ile bu durumu açıklamaya çalışmışlardır (20). Ayrıca MA ve MOA adenokarsinomların moleküler değerlendirmelerde önemli farklılıklar ortaya çıkmıştır. MA'da MUC2 proteininin aşırı ekspresyonu, MOA 'dan ayıran en belirgin moleküler anormalliklerden biridir (21). Bunun dışında mikrosatellit instabilitesi, BRAF mutasyonları, serin/treonin kinaz mutasyonlarının MA'larda daha sık görülmesi yüksek metastaz riski ve kötü prognozla ilişkili olduğu bildirilmiştir (22).

Kolorektal kanserlerde tedavi başarısını artırmak için kanserlerin alt tiplerine, histolojik ve genetik özelliklerine dayalı bireyselleştirilmiş tedavilerin geliştirilmesi gerekmektedir. Ancak günümüzde MA için spesifik tedavi rejimleri bulunmadığından diğer kolorektal kanserler gibi tedavi edilmektedir. Bununla birlikte mevcut neoadjuvan ve adjuvan kemoterapi tedavilerinin MA'da daha az etkili olduğu gösteren birçok çalışma mevcuttur (21).

Kolorektal karsinomların tedavisinde immünoterapi, hedeflenmiş moleküler terapi, nano partikül ilaçlar gibi gelişmekte olan birçok tedavi yöntemi mevcuttur (21). Bu tedavilerin etkisinin artırılması için kolorektal kanserlerin alt tiplerinin genetik ve patolojik özelliklerinin tanımlanmasına ihtiyaç vardır.

Çalışmamızın çeşitli limitasyonları mevcuttur. Bunlar; tek merkezli olmas1, örneklem büyüklüğünün az olması, hastalıksız sağkalımın hesaplanamaması, kemoradyoterapi protokollerine ulaşılamaması ve genetik testlerin eksiliği olarak sayılabilir. Buna rağmen çalışmamız bu konuda yapılan nadir çalışmalardan olması ve müsinöz adenokarsinomun prognostik özelliğinin gösterilmesi açısından önemlidir.

$\mathrm{Bu}$ çalışmada, MA ve MOA hastalarının sağkalım oranlarını karşılaştırdık ve MA hastaları, MOA hastalarından anlamlı olarak daha kötü sağkalıma sahip olduğu gördük. Ayrıca, yapılan çok değişkenli analizde de MA histolojisinin bağımsız bir prognostik faktör olduğunu göstermiş olduk. Sonuç olarak MA'un biyolojik davranışı müsinöz olmayan adenokarsinomlara göre daha kötüdür bundan dolayı tedavi ve takiplerinde daha dikkatli olunması gerekir.

\section{REFERANSLAR}

1. Weitz J, Koch M, Debus J, Hohler T, Galle PR, Buchler MW: Colorectal cancer. Lancet 2005, 365:153-65.

2. Bosman FT, Carneiro F, Hruban RH, et al. WHO Classification of Tumours of the Digestive System, 4th edn. Geneva, Switzerland: World Health Organization, International Agency for Research on Cancer; 2010.

3. Du W, Mah JT, Lee J, et al. Incidence and survival of mucinous adenocarcinoma of the colorectum: a population-based study from an Asian country. Dis Colon Rectum. 2004;47:78-85.

4. Chew MH, Yeo SA, Ng ZP, et al. Critical analysis of mucin and signet ring cell as prognostic factors in an Asian population of 2,764 sporadic colorectal cancers. Int J Colorectal Dis. 2010;25: 1221-9.

5. Lee WS, Chun HK, Lee WY, et al. Treatment outcomes in patients with signet ring cell carcinoma of the colorectum. Am J Surg. 2007;194:294-298. Kang H, O'Connell JB, Maggard MA, et al. A 10year outcome evaluation of mucinous and signetring cell carcinoma of the colon and rectum. Dis Colon Rectum. 2005;48:1161-8.

6. Zhang H, Evertsson S, Sun X: Clinicopathological and genetic characteristics of mucinous carcinomas in the colorectum. Int J Oncol 1999, 14:1057-61.

7. Kim DH, Kim JW, Cho JH, et al. Expression of mucin core proteins, trefoil factors, APC and p21 in subsets of colorectal polyps and cancers suggests a distinct pathway of pathogenesis of mucinous carcinoma of the colorectum. Int J Oncol 2005, 27:957-64.

8. Song GA, Deng G, Bell I, Kakar S, Sleisenger MH, Kim YS: Mucinous carcinomas of the colorectum have distinct molecular genetic characteristics. Int J Oncol 2005, 26:745-50.

9. Brenner H, Kloor M, Pox CP: Colorectal cancer. Lancet 2014; 383: 1490-1502.

10. Van de Velde CJ, Boelens PG, Borras JM, et al: EURECCA colorectal: multidisciplinary management: European consensus conference colon \&amp; rectum. Eur J Cancer 2014; 50(1): 134 
11. Van Cutsem E, Cervantes A, Nordlinger B, Arnold D; ESMO Guidelines Working Group: Metastatic colorectal cancer: ESMO Clinical Practice Guidelines for diagnosis, treatment and follow-up. Ann Oncol 2014; 25(3): 1-9.

12. Papadopoulos VN, Michalopoulos A, Netta S,et al Prognostic significance of mucinous component in colorectal carcinoma. Tech Coloproctol 2004;8(1):123-5.

13. Consorti F, Lorenzotti A, Midiri G, Di Paola M: Prognostic significance of mucinous carcinoma of colon and rectum: a prospective case-control study. J Surg Oncol 2000; 73: 70-4.

14. Hyngstrom JR, $\mathrm{Hu} \mathrm{CY}$, Xing $\mathrm{Y}$, et al Clinicopathology and outcomes for mucinous and signet ring colorectal adenocarcinoma: analysis from the National Cancer Data Base. Ann Surg Oncol 2012; 19: 2814-21.

15. Hugen $\mathrm{N}$, Verhoeven $\mathrm{RH}$, Radema $\mathrm{SA}$, et al. Prognosis and value of adjuvant chemotherapy in stage III mucinous colorectal carcinoma. Ann Oncol. 2013;24(11):2819-24.

16. Numata $M$, Shiozawa $M$, Watanabe $T$, et al. The clinicopathological features of colorectal mucinous adenocarcinoma and a therapeutic strategy for the disease. World J Surg Oncol. 2012;10(1):109
17. Compton $\mathrm{C}$, Fenoglio-Preiser CM, Pettigrew N, Fielding LP: American Joint Committee on Cancer Prognostic Factors Consensus Conference: Colorectal Working Group. Cancer 2000, 88:173957.

18. Hosseini S, Bananzadeh A.M., Salek R, ZareBandamiri M, Kermani A T, Mohammadianpanah M. Prognostic Significance of Mucinous Histologic Subtype on Oncologic Outcomes in Patients With Colorectal Cancer Ann Coloproctol 2017;33(2):5763

19. Hosseini S, Zohourinia S, Zare-Bandamiri M, et al. Clinical and pathological characteristics of mucinous colorectal adenocarcinoma: a comparative study. Ann Colorectal Res 2016;4:e34404.

20. Sugarbaker PH: Mucinous colorectal carcinoma. J Surg Oncol 2001, 77: 282-3.

21. Cong Luo, Shuyi Cen, Guojun Ding, Wei Wu Mucinous colorectal adenocarcinoma: clinical pathology and treatment options. Cancer Communications, 2019, 39: 13.

22. Zong, Z., Luo, Y., Ying, H., Wang, A., Li, H., Yi, C. Trends of incidence and survival in patients with gastrointestinal mucinous adenocarcinoma. Oncology letters, (2018); 16(5): 5791-5798. 